\title{
Tuberculosis cross-species transmission in Tanzania: Towards a One-Health concept
}

\author{
Authors: \\ Erasto V. Mbugi ${ }^{1,2}$ \\ Bugwesa Z. Katale ${ }^{1,3}$ \\ Sharon Kendall ${ }^{4}$ \\ Liam Good ${ }^{4}$ \\ Gibson S. Kibiki ${ }^{5}$ \\ Julius D. Keyyu ${ }^{3}$ \\ Peter Godfrey-Faussett ${ }^{6}$ \\ Paul van Helden ${ }^{7}$ \\ Mecky I. Matee \\ Affiliations: \\ ${ }^{1}$ Departments of \\ Microbiology and \\ Immunology, Muhimbili \\ University of Health and \\ Allied Sciences, Tanzania \\ ${ }^{2}$ Department of Biochemistry, \\ Muhimbili University of Healt \\ and Allied Sciences, Tanzania \\ ${ }^{3}$ Tanzania Wildlife Research \\ Institute, Arusha, Tanzania \\ ${ }^{4}$ The Royal Veterinary College, \\ London, United Kingdom \\ ${ }^{5}$ Kilimanjaro Christian \\ Medical College, Tumaini \\ University, Tanzania \\ ${ }^{6}$ London School of Hygiene \\ and Tropical Medicine, \\ London, United Kingdom \\ ${ }^{7}$ DST/NRF Centre of \\ Excellence for Biomedical \\ Tuberculosis Research/MRC \\ Centre of Molecular and \\ Cellular Biology, Division \\ of Molecular Biology and \\ Human Genetics, Faculty of \\ Health Sciences, University \\ of Stellenbosch, \\ South Africa \\ Correspondence to: \\ Erasto Mbugi \\ Email: \\ erasto.mbugi@sacids.org \\ Postal address: \\ PO Box 65001, Dar es Salaam, \\ Tanzania \\ How to cite this proceeding \\ Mbugi, E.V., Katale, B.Z. \\ Kendall, S., Good, L., Kibik, \\ G.S., Keyyu, J.D. et al., 2012 \\ 'Tuberculosis cross-species \\ transmission in Tanzania: \\ Towards a One-Health \\ concept', Onderstepoort \\ Journal of Veterinary Research \\ 79(2), Art. \#501, 6 pages. \\ http://dx.doi.org/10.4102/ojvr. \\ v79i2.501

\section{Note:} \\ Proceedings of the Conference \\ of the Southern African \\ Centre for Infectious Disease \\ Surveillance 'One Health' \\ held at the National Institute \\ for Communicable Diseases, \\ Johannesburg, July 2011. This \\ article was republished with \\ the author's full affiliation
}

For centuries, tuberculosis, which is a chronic infection caused by the bacillus Mycobacterium tuberculosis has remained a global health problem. The global burden of tuberculosis has increased, particularly in the Southern African region, mainly due to HIV, and inadequate health systems which has in turn given rise to emergent drug resistant tuberculosis (TB) strains. Bovine tuberculosis (BTB) has also emerged as a significant disease with the tendency for inter-species spread. The extent of interspecies BTB transmission both in urban and rural communities has not been adequately assessed. The phenomenon is of particular importance in rural communities where people share habitats with livestock and wildlife (particularly in areas near national parks and game reserves). Aerosol and oral intake are the major routes of transmission from diseased to healthy individuals, with health care workers often contracting infection nosocomially. Although TB control has increasingly been achieved in high-income countries, the disease, like other poverty-related infections, has continued to be a disaster in countries with low income economies. Transmission of infections occurs not only amongst humans but also between animals and humans (and occasionally vice versa) necessitating assessment of the extent of transmission at their interface. This review explores tuberculosis as a disease of humans which can cross-transmit between humans, livestock and wildlife. The review also addresses issues underlying the use of molecular biology, genetic sequencing and bioinformatics as tools to understand the extent of inter-species cross-transmission of TB in a 'One Health' context.

\section{Introduction}

Humans and animals have had close interactions as long as we have historical knowledge of man. This interaction largely contributes to the evolution and ongoing transmission of shared infectious diseases. The need for a systematic global effort to monitor for emerging human is important since most major human infectious diseases are thought to have animal origins (Wolfe, Dunavan \& Diamond 2007), examples being helminths, tuberculosis (TB), brucellosis, foot-andmouth disease, leptospirosis, anthrax and Rift Valley fever (RVF). Studies on 1415 pathogenic diseases in human and animals (Cleaveland, Laurenson \& Taylor 2001) have revealed $61.6 \%$ as multi-host pathogens, suggesting the need for monitoring these important infectious diseases.

Available data indicate that more than $80 \%$ of human and cattle populations of Africa live in an area with partial or no control of bovine TB (Cosivi et al. 1998; WHO/DFID 2006; WHO 2004). There is ample evidence that such lack of control and close contact of the two species contributes to TB transmission, mostly Mycobacterium bovis from cattle to humans. Perhaps the best-studied example and illustration of the effectiveness of control measures was the situation in Western Europe (Germany as a good example) prior to the 1950s, where M. bovis infection in cattle was common, and M. bovis was present in perhaps $15 \%$ of human cases. After strict control measures were introduced, $M$. bovis prevalence dropped effectively to zero in both species, with only the occasional reactivation case seen in the elderly, or in new immigrants coming from areas where $M$. bovis is not controlled. The extent of M. bovis infection and disease is not properly known in almost every environment. Many tests, for example, tuberculin skin test (TST) and assays based on gamma interferon response may indicate exposure, but neither indicates disease nor an indication of whether infection is from Mycobacterium tuberculosis, M. bovis, or possibly other mycobacteria, particularly those of the $M$. tuberculosis complex. The usual assumption is that if the test is done in a bovid, then the presence of or exposure to M. bovis is indicated, whereas if done in humans, then M. tuberculosis is indicated. However, this may not be true, since cross-reactivity does occur. At this stage, the gold standard for identification remains microbiological, whether culture or done by molecular techniques. Tuberculosis can present in many ways, and in humans, a frequent manifestation of bovine TB is extra-pulmonary tuberculosis (EPTB). Unfortunately, M. tuberculosis can also present in extra-pulmonary form, although less frequently. Extra-pulmonary tuberculosis driven by $M$. tuberculosis can also occur more frequently in children and individuals who are

C 2012. The Authors. Licensee: AOSIS OpenJournals. This work is licensed under the Creative Commons Attribution License. 
immunocompromised, for example, HIV positive (Connolly et al. 2004; Heymann 2011). Therefore, although EPTB can be used as an indicator (or rather, index of suspicion) of M. bovis infection in humans, this should only be considered seriously in areas or individuals where exposure to bovine TB is likely or suspected. Nevertheless, EPTB prevalence can be used as an indicator of M. bovis in humans. The control of this disease clearly requires significant efforts on the part of both veterinary and human health care practitioners and this article will address this cross-species issue in particular.

\section{Transmission at the human- livestock-wildlife interface}

Transmission of bovine tuberculosis from animals to humans can occur most likely via aerosol exposure or through consumption of un-pasteurised milk and other affected animal products. Reports from Tanzania covering the period from 2008 to 2009 suggest that EPTB accounted for over $20 \%$ of the cases of TB and showed a marginal annual increment (National TB Control Program Report 2011, in preparation). This high level prevalence of EPTB plus other data (Cook et al. 1996) suggests the presence of mycobacteria other than M. tuberculosis occur extensively in the Tanzanian population. We note that more extra-pulmonary cases are contributed by $M$. tuberculosis than M. bovis by total case load; however, such a high prevalence rate is unlikely to be due entirely to M. tuberculosis. A study by Cook et al. (1996) in Monze District of Zambia, reported for cattle in larger herds, in households with previously report of human tuberculosis cases (preceding 12 months) to be more likely tuberculin test positive (six times) than those without previous reported human TB case. This could reflect TB cross-transmission between species. In the same year, a variety of different mycobacteria, including M. tuberculosis, were isolated from dairy cattle and milk in Tanzania (Kazwala et al. 1998). Studies in the Netherlands (Majoor et al. 2011) indicate mainly (58.9\%) extra-pulmonary $M$. bovis infection in humans. Although individuals may develop the pulmonary form of $M$. bovis disease, personto-person transmission is said to be unlikely, based on data from genotype analysis (Majoor et al. 2011). There are reports on elephant-to-human transmission of tuberculosis due to indirect exposure to aerosolised M. tuberculosis (Murphree et al. 2011). The infection has been exacerbated by delayed or inadequate disease control practices. Other reports have indicated M. tuberculosis as an emerging disease in Asian elephants in zoological collections (Mikota et al. 2001). Finally, there are unpublished reports that $M$. tuberculosis has been detected in a number of Ethiopian cattle, transferred from the human owners directly to the animals (Paul van Helden from D Young pers. comm., n.d.).

The implication, impact and challenges underlying zoonotic tuberculosis to both humans and animals has been repeatedly emphasised (Cataldi \& Romano 2007; Cleaveland et al. 2005; Kazwala et al. 1998, 2001a; Michel 2002b; Michel et al. 2006; Michel, Müller \& Van Helden 2010; Woodroffe et al. 2009). Yet diagnosis by acid fast smear is still widely used and often the only non-clinical diagnostic since it is affordable. But this test, despite being the keystone of tuberculosis diagnosis in Africa, does not permit differentiation between $M$. tuberculosis and $M$. bovis, or any other mycobacterial species. Thus, it is essential that better diagnostics are applied in order that we may know the extent and nature of the problem at hand. In addition, the conventional means of control are difficulty to apply once the infection enters into wildlife species which are common maintenance hosts in most cases (Michel 2002a; Palmer 2007). Animals are regarded to be the main source of zoonotic tuberculosis infection in humans. However, as outlined above, reports also indicate that humans are not the only victims from cross-species infection by tuberculosis, but are also potential sources of infection, even to free-living wildlife at their interface (Alexander et al. 2002). This creates room for researchers to look at the disease from both sides of the coin. Aerosol and oral transmission are the major routes of transmission in patients, with health care workers contracting infection nosocomially. In wildlife, similar routes are proposed with carnivores and omnivores said to contract infections via scavenging of bovine tuberculosis infected carcasses and killing and consumption of infected prey such as antelope or wild bovids (Michel et al. 2006). This is evident from proven bovine tuberculosis in predators (Keet et al. 2001).

Intensification of animal-human contact enhances the likelihood of cross-over and an increased risk of transmission for both $M$. tuberculosis as well as M. bovis at the interface. Cross-transmission in infectious disease is not a newly emerging view but linked to the co-evolution of humans, the animals with which they co-exist and evolve and the microorganisms in their environment (Diamond 2002; Wirth et al. 2008). Once a pathogen has crossed over into a new species of host, for example from animal to human, it may transform into a specialised pathogen of humans Wolfe et al. (2007).

A number of studies have been done reflecting the impact bovine tuberculosis may pose to wildlife (Alexander et al. 2002; Cleaveland et al. 2005; De Garine-Wichatitsky et al. 2010; Michel et al. 2006, 2007). Others have focused on livestock alone (Aranaz et al. 2003; Cousins 2001; Durnez et al. 2009, 2011; Shirima, Kazwala \& Kambarage 2003; Kazwala et al., 2001b) and others in humans alone (Kazwala et al. 1998; Mfinanga et al. 2004; Ngowi et al. 2008), mostly using conventional diagnostic and evaluation means of the disease. A review published recently (Michel et al. 2010) pinpointed bovine tuberculosis in particular, to be a disease of low-income countries with a multifaceted impact affecting the health of livestock, humans and the ecosystems. In the same review, it is also speculated that the disease is likely to increase in situations where HIV and AIDS occurs.

Recent work has characterised M. bovis isolates and reported that regional clonal complexes predominating in specific areas occur, for example Af1 M. bovis complex in westcentral Africa (Muller et al. 2009), Af2 prevalent in East Africa (Berg et al. 2011) as well as European 1 with European origin (Smith et al.2011). Thus we do not yet know for certain whether 
M. bovis is an endemic or alien disease to Africa, or whether it is endemic to some areas (e.g. some parts of West and East Africa) but alien to others. Certainly, there is no evidence to suggest that any form of M. bovis is endemic or indigenous to South Africa. Better unpacking of this information is needed, since it may impact on how we view this disease and respond to it. We do not know the relative frequency of the African and European type M. bovis in any area and it may be that the European variety dominates as an alien invasive organism. It may be that indigenous African cattle and wildlife in some areas are relatively resistant to bovine $\mathrm{TB}$, which we may take advantage of in our responses to the disease.

Several studies and reviews surveying the zoonotic TB status in animals and humans have been published (Cataldi \& Romano 2007). Different study designs, methods of analysis and various study-dependent objectives largely influence the outcome and interpretation of these studies. Differences in outcomes amongst these different studies nevertheless reflect the diversity of disease dynamics in different communities and methodological shortcomings have been revealed (Heldal et al. 2003; Murray \& Alland 2002).

A new concern is that cross-species transmission may play a role in emergent drug resistant tuberculosis. Mycobacterium bovis is inherently resistant to pyrazinamide, one of the four first line antibiotics, and thus inadequate and / or inappropriate treatment of apparent M. tuberculosis in a human can easily result in acquisition of further resistance in M. bovis. Drug-resistant $M$. bovis in human disease has already been reported in a number of countries (Blazquez et al. 1997; Hughes et al. 2003; Sechi et al. 2001). This is essentially risky for African populations due to a close association of TB with HIV and often poor patient adherence and problems with implementing a good DOTS programme as advocated by Word Health Organisation (WHO). Likewise, transmission of drug resistant $M$. tuberculosis to animals and back to humans is not impossible, although likely to be very rare. In rural communities, milk pasteurisation is not common and M. bovis survival in cow's milk is effective. Therefore, despite reports that humans are less susceptible to bovine TB than M. tuberculosis (De la Rua-Domenech 2006) we cannot ignore these known problems and complications.

\section{Possible contributing factors to increased transmission at the interface}

The main problem with identifying or quantifying the transmission of zoonotic tuberculosis at the human-animal interface is the failure to adopt appropriate diagnostic tools that can discriminate between M. bovis and M. tuberculosis, or other species of mycobacteria at routine diagnostic settings, particularly in low-income countries. This is not surprising, given the huge burden of disease, particularly of M. tuberculosis and the low per capita income of those countries. A further reason for this problem is that many clinicians show no interest in differentiating the causative agent, since initial treatment is the same. As a result the contribution of mycobacteria such as $M$. bovis to the global human TB burden is almost certainly underestimated. Despite these problem and long before such discriminatory tests became available, the test-and-slaughter scheme has proven to be an efficient control method for bovine tuberculosis in developed countries, although it is considered expensive (Michel et al. 2010) and is not yet accepted by all farmers (Bennett 2009; Torgerson \& Torgerson 2009). Consequently, the joint impact of these important pathogens to national and global economies is still unknown.

Different and inflexible policies guiding the practice of veterinary and medical practitioners are also potential barriers to what may be an immediate positive impact on zoonotic TB control strategies in most developing countries. The prevalence of human TB and livestock TB has been reported to correlate (Cosivi et al. 1998) despite contradicting reports on animal-human active transmission of zoonotic TB (Cousins, Williams \& Dawson 1999; Dankner \& Davis 2000; Dankner et al. 1993; Jalava et al. 2007; Romano et al. 1995, 1996; Zumarraga et al. 1999). The absence of genetic relatedness amongst $M$. bovis isolates leading to these controversies is in all likelihood simply a matter of incomplete sampling and reactivation disease (Mignard, Pichat \& Carret 2006). This is supported by a report from Baker et al. (2006) who found many genotypes in human TB identical to patterns from farmed and wild animals. With the current advancement in molecular techniques for evaluation of infectious agents, exploiting these skills and using them for both epidemiological and evolutionary analysis of mycobacterial populations infecting humans and animals (Baker et al. 2004) and assessment of their cross-transmission amongst these species is possible and important.

Pathogen flow and disease dynamics of $M$. bovis has been broadly reported in South Africa's wildlife and livestock (Michel 2002b; Michel et al. 2006, 2010) showing that the African buffalo is the major reservoir of infection in wildlife in that ecosystem. Thus, although originally a naïve host and infected by cross-over from cattle initially, the buffalo have become a source of infection for many other species, through dissemination of bacilli in the environment or predation (Keet et al. 1996; Michel 2002a, 2002b; Michel et al. 2004, 2006, 2007, 2010). Although fairly the extensive studies have been done in the South African National Parks, little has been done in the large National Parks of Tanzania, such as Serengeti, Ruaha and Mikumi, where a large number of buffaloes are found. Unlike the South African parks, where there is little or no contact with domestic stock, in Tanzania infected buffalo could be reservoirs of bovine TB contributing to the increasing prevalence of tuberculosis in both humans and livestock, through mechanisms described below.

Some legal and controlled hunting is allowed in open areas, Game Controlled Areas (GCAs) and game reserves for gamemeat in Tanzania but there is no established meat inspection to monitor TB or other infections in these game products. In addition, people around game reserves and national parks practice illegal or bush meat hunting and hidden sale of 
game meat in villages and therefore difficult to control or conduct meat inspection. The situation is worsened during extensive droughts when food becomes scarce, resulting in increased poaching activities. In such circumstances, the contact between species at their interface and probability of infected meat entering the human food chain may increase with consequent spillover and cross-transmission of infection amongst populations (Osofsky et al. 2005). In addition, the life expectancy of livestock held by small scale farmers is generally higher than in commercial livestock keeping and bovine tuberculosis as a chronic and progressive disease manifests itself more often in older animals, under nutritional or productive stress (Michel et al. 2006). This socio-cultural behaviour when combined with close proximity with wildlife is detrimental to either ecosystem in terms of tuberculosis cross-transmission.

\section{Molecular epidemiological - diagnostic tools and their application in developing countries}

The development of molecular tools for identification of M. bovis, the known zoonotic TB causing mycobacterium, and differentiation from other members of the M. tuberculosis complex have allowed the discovery of more cases in retrospective studies and have suggested new forms of transmission (Cataldi \& Romano 2007). In addition, the usefulness of molecular tools in normal practices of prevention and control of tuberculosis has been addressed (McNabb, Braden \&Navin 2002). Genotyping of mycobacterial isolates in the mycobacterium tuberculosis complex has the ability to distinguish amongst clonal populations and provide key information on disease dynamics. However, this approach has been insufficiently applied in developing countries due to lack of facilities, resources and scarce skilled personnel. Molecular techniques such as PCR are powerful tools to identify mycobacteria and can potentially be used on cultured and original biological samples. Application of more than one molecular technique can complement each other in differentiating various strains or isolates and shed light on the phylogenetics and ultimately the transmission chains, thereby allowing for improved control or policy development (Michel et al. 2010).

Such actions require specific and dedicated support and government commitment for wide use and sustainability. Very few molecular epidemiological studies on tuberculosis have been done in Tanzania and even those few have been made possible mainly through collaborations. These studies have focused on the epidemiology of the disease in livestock or in wildlife, or have dealt with the disease in humans. As yet, tracking transmission across species using molecular tools such as RFLP (Michel 2002b) in Tanzania has been limited or almost non-existent.

\section{One Health as a Disease control strategy}

Management of diseases in wildlife is complex because the current wildlife policy in Tanzania does not generally advocate treatment or vaccination to control infection and disease. Treatment or vaccination is only allowed if a disease outbreak occurs in endangered wildlife species or the outbreak poses a threat to the species population. Of course it must also be acknowledged that vaccination is not effective in all diseases, TB being one such example. Moreover, the logistics and funding required for treatment or vaccination in wildlife also make it largely impractical because it is almost impossible to get all animals, except perhaps very rare species (Osofsky et al. 2005). In most of Africa, small scale farmer's livestock and their products are largely excluded from veterinary and veterinary public health control measures (Michel et al. 2004). Therefore, a change in policy and the political will that is necessary to support such recommendations will be necessary to reduce infection and disease. We need a two-pronged approach to address both technical and political issues to formulate a way forward. A policy that is focused on control of zoonotic TB and which addresses the need for a 'One Health' approach, through which veterinary and medical professions as well as social scientists and ecologists can work together to limit disease would be a new venture with a chance of success.

\section{Conclusions}

Due to differences in national policies which guide different sectors of the Tanzanian economy (health, livestock and wildlife), the immediate suggested approach would be to prevent contact between wildlife and livestock and to control the disease (TB) in livestock through introduction of a compulsory test and slaughter practice, a proven recipe in other countries. This will reduce the transmission of disease not only between livestock and humans, but also limit transmission of infection from wildlife and vice versa. The implementation should include a policy that strictly prohibits livestock introgression to national parks and game reserves by implementing a boundary, beyond which animal keeping is unlawful. This however, has a problem in that even if livestock are kept out of this zone, wildlife will not understand that zone and will move into it, such that the 'zone' will then move outwards to contact livestock again posing a big challenge on the strategy. The other remaining challenge is to convince policy makers and creating awareness in livestock keepers concerning the magnitude of the problem its consequences and the importance of disease control even impacts across international borders. The Serengeti National Park, for example, spans two countries and animal movement to the other side of the park into the Kenyan Maasai Mara might be contributing to an increased transmission risk not only to the wildlife in that country but also the livestock and humans in the neighbouring country. This is also applicable from Kenya to Tanzania, of course, as it would be for any transfrontier park.

Although some work has been done we still do not have any accurate estimate of the extent of human-animal cross-species transmission in Tanzania, possibly elsewhere, with regard to TB. Much of this is because of the technical complexity and cost of cultures and speciation. In addition, additional 
problems include bias in previous studies owing to sampling from urban areas and pulmonary samples as well as challenge of detecting infection rather than disease and attributing it to transmission, together with the assumption that it is a particular species of mycobacterium. Studies are currently underway in and around the Serengeti National Park under the umbrella of the Southern Centre for Infectious Disease Surveillance (SACIDS), to try to establish the clear transboundary interaction between human-livestock-wildlife and TB transmission. Once one has a clear understanding of these factors, it may be possible to suggest an appropriate 'One Health' approach to arrest pathogen flow and interrupt prevailing disease dynamics across species. In our opinion, research aiming to identify and characterise pathogens (not only mycobacterial species) of animals with potential to be infective to humans (Wolfe et al. 2007) should be prioritised in order to enable us know the potential source of diseases to become proactive and hopefully prevent or limit outbreaks. To successfully implement this strategy, a sustainable and efficient collaborative approach involving multiple stakeholders from various sectors and working groups is needed.

\section{Acknowledgement}

The SACIDS is acknowledged for providing a Postdoctoral Research Fellowship to EM. Financial support was received from the Wellcome Trust. Prof. Mark Rweyemamu, The Executive Director of SACIDS is acknowledged for stimulating the idea and advice. The London International Development Centre in the UK and staff are acknowledged for collaboration. Prof. Jeff Waage is particularly acknowledged for his dedicated efforts to provide complementary material support and encouragement during preparation of this manuscript. Sian Brown and Sue van Rensburg are acknowledged for the illustrative pictures used in this manuscript. Muhimbili University of Health and Allied Science, particularly, the School of Medicine and The Department of Biochemistry are acknowledged for providing time for preparation of this work.

\section{Competing interests}

The authors declare that they have no financial or personal relationship(s) which may have inappropriately influenced them in writing this paper.

\section{Authors' contributions}

E.V.M. (Muhimbili University of Health and Allied Sciences) participated in reviewing the literature, conceptualising, drafting and writing the manuscript. B.Z.K. (Muhimbili University of Health and Allied Sciences) participated in initial drafting of the manuscript and critical manuscript review. S.K. (The Royal Veterinary College) participated in critical manuscript review. L.G. (The Royal Veterinary College) assisted in critical manuscript review and focusing of the manuscript. G.S.K. (Tumaini University) critically reviewed the manuscript. J.D.K. (Tanzania Wildlife Research
Institute) conceived the idea, assisted in drafting and critical review of the manuscript. P.v.H. (University of Stellenbosch) assisted in critical review of the manuscript. P.G.F. (London School of Hygiene and Tropical Medicine) assisted in drafting the manuscript and critically reviewed the manuscript. M.I.M. (Muhimbili University of Health and Allied Sciences) directed the whole process of drafting and critical review of manuscript.

\section{References}

Alexander, K.A., Pleydell, E., Williams, M.C., Lane, E.P., Nyange, J.F. \& Michel, A.L., 2002, 'Mycobacterium tuberculosis: An emerging disease of free-ranging wildife, Emerging Infectious Diseases 8, 598-601. http://dx.doi.org/10.3201/ eid0806.010358, PMid:12023916

Aranaz, A., Cousins, D., Mateos, A. \& Domı'Nguez, L., 2003, 'Elevation of Mycobacterium tuberculosis subsp. caprae Aranaz et al. 1999 to species rank as Mycobacterium caprae comb. nov., sp. nov.', International Journal of Systematic and Evolutionary Microbiology 53, 1785-1789.

Baker, L., Brown, T., Maiden, M.C. \& Drobniewski, F., 2004, 'Silent nucleotide polymorphisms and a phylogeny for Mycobacterium tuberculosis', Emerging Infectious Diseases 10, 1568-1577. http://dx.doi.org/10.3201/eid1009.040046, PMid:15498158

Baker, M.G., Lopez, L.D., Cannon, M.C., De Lisle, G.W. \& Collins, D.M., 2006 'Continuing Mycobacterium bovis transmission from animals to humans in New Zealand', Epidemiology and Infection 134, 1068-1073. http://dx.doi.org/10.1017/ S0950268806005930, PMid:16569268

Bennett, R.M., 2009, 'Farm costs associated with premovement testing for bovine tuberculosis', Veterinary Record 164, 77-79. http://dx.doi.org/10.1136/ vr.164.3.77, PMid:19151404

Berg, S., Garcia-Pelayo, M.C., Muller, B., Hailu, E., Asiimwe, B., Kremer, K. et al., 2011, 'African 2, a clonal complex of Mycobacterium bovis Epidemiologically Important in East Africa', Journal of Bacteriology 193, 670-678. http://dx.doi.org/10.1128/ JB.00750-10, PMid:21097608

Blazquez, J., De Los, E., Monteros, L.E., Samper, S., Martin, C., Guerrero, A. et al., 1997 'Genetic characterization of multidrug-resistant Mycobacterium bovis strains from a hospital outbreak involving human immunodeficiency virus- positive patients', Journal of Clinical Microbiology 35, 1390-1393. PMid:9163450

Brosch, R., Gordon, S.V., Marmiesse, M., Brodin, P., Buchrieser, C., Eiglmeier, K. et al 2002, 'A new evolutionary scenario for the Mycobacterium tuberculosis complex',
Proceedings of the National Academy of Sciences of the United States of America Proceedings of the National Academy of Sciences of the United States of America

Cataldi, A. \& Romano, M.I., 2007, 'Tuberculosis caused by other members of the Mycobacterium tuberculosis complex', in Tuberculosis: From basic science to patient care, viewed n.d., from http://www.tuberculosis.textbook.com

Cleaveland, S., Laurenson, M.K. \& Taylor, L.H., 2001, 'Diseases of humans and their domestic mammals: Pathogen characteristics, host range and the risk of emergence', Philosophical Transactions of the Royal Society of London. Series B: Biological Sciences 356, 991-999. http://dx.doi.org/10.1098/rstb.2001.0889, PMid:11516377

Cleaveland, S., Mlengeya, T., Kazwala, R.R., Michel, A., Kaare, M.T., Jones, S.L. et al., 2005, 'Tuberculosis in Tanzanian wildlife', Journal of Wildlife Diseases 41, 446453. PMid:16107683

Cook, A.J.C., Tuchili, L.M., Buve, A., Foster, S.D., Godfrey-Faussett, P., Pandey, G.S et al., 1996, 'Human and bovine tuberculosis in the Monze District of Zambia: A cross-sectional study', British Veterinary Journal 152, 37-46. http://dx.doi. org/10.1016/S0007-1935(96)80084-4

Connolly, M.A., Gayer, M., Ryan, M.J., Salama, P., Spiegel, P. \& Heymann, D.L., 2004 'Communicable diseases in complex emergencies: Impact and challenges', The Lancet 364, 1974-1983. http://dx.doi.org/10.1016/S0140-6736(04)17481-3

Cosivi, O., Grange, J.M., Daborn, C.J., Raviglione, M.C., Fujikura, T., Cousins, D. et al., 1998, 'Zoonotic tuberculosis due to Mycobacterium bovis in developing countries', Emerging Infectious Diseases 4, 59-70. http://dx.doi.org/10.3201/ eid0401.980108, PMid:9452399

Cousins, D.V., 2001, 'Mycobacterium bovis infection and control in domestic livestock', Scientific and Technical Review of the International Office of Epizootics 20, 71-85.

Cousins, D.V., Williams, S.N. \& Dawson, D.J., 1999, 'Tuberculosis due to Mycobacterium bovis in the Australian population: DNA typing of isolates, 1970-1994', International Journal of Tuberculosis and Lung Disease 3, 722-731. PMid:10460106

Dankner, W.M. \& Davis, C.E., 2000, 'Mycobacterium bovis as a significant cause of tuberculosis in children residing along the United States-Mexico Border in the Baja California Region', Pediatrics 105, e79. http://dx.doi.org/10.1542/ peds.105.6.e79, PMid:10835092

Dankner, W.M., Waecker, N.J., Essey, M.A., Moser, K., Thompson, M. \& Davis, C.H 1993, 'Mycobacterium bovis infections in San Diego: A clinico-epidemiologic study of 73 patients and a historical review of a forgotten pathogen', Medicine (Baltimore) 72, 11-37.

De Garine-Wichatitsky, M., Caron, A., Gomo, C., Foggin, C., Dutlow, K., Pfukenyi, D. et al., 2010, 'Bovine tuberculosis in buffaloes, Southern Africa', Emerging Infectious Diseases 16, 884-885. PMid:20409396 
De La Rua-Domenech, R., 2006, 'Human Mycobacterium bovis infection in the United Kingdom: Incidence, risks, control measures and review of the zoonotic aspects of bovine tuberculosis', Tuberculosis 86, 77-109. http://dx.doi.org/10.1016/j. of bovine tuberculosis, 1 Tuberculosis
tube.2005.05.002, PMid:16257579

Diamond, J., 2002, 'Evolution, consequences and future of plant and animal domestication', Nature 418, 700-707. http://dx.doi.org/10.1038/nature01019, PMid:12167878

Durnez, L., Katakweba, A., Sadiki, H., Katholi, C.R., Kazwala, R.R., Machang'u, R.R. et al., 2011, 'Mycobacteria in terrestrial small mammals on cattle farms in Tanzania', Veterinary Medicine International 2011, 1-12. http://dx.doi. org/10.4061/2011/495074, PMid:21785686

Durnez, L., Sadiki, H., Katakweba, A., Machang'u, R., Kazwala, R., Leirs, H. et al., 2009 'The prevalence of Mycobacterium bovis-infection and atypical mycobacterioses in cattle in and around Morogoro, Tanzania', Tropical Animal Health and Production in cattle in and around Morogoro, Tanzania', Tropical Animal Health and Production

García-Pachón, E. \& Rodríguez, J.C., 2005, 'Molecular rpidemiology of tuberculosis: Main findings and their application in Spain', Archives of Bronconeumology 41, 618-624. http://dx.doi.org/10.1016/S1579-2129(06)60296-6

Heymann, D.L., 2011, 'Control of Communicable Diseases Manual 18th edition: Tuberculosis', ICD-9 010-018; ICD-10 A15-A19, viewed n.d., from http://myph org/html/CCDM_Tuberculosis.html

Heldal, E., Dahle, U.R., Sandven, P., Caugant, D.A., Brattaas, N., Waaler, H.T. et al. 2003, 'Risk factors for recent transmission of Mycobacterium tuberculosis', 2003, 'Risk factors for recent transmission of Mycobacterium tuberculosis',
European Respiratory Journal 22, 637-642. http://dx.doi.org/10.1183/09031936. European Respiratory Journal 22

Hughes, V.M., Skuce, R., Doig, C., Stevenson, K., Sharp, J.M. \& Watt, B., 2003, 'Analysis of multidrug-resistant $M$. bovis from three clinical samples from Scotland', International Journal of Tuberculosis and Lung Diseases 7, 1191-1198. PMid:14677895

Jalava, K., Jones, J.A., Goodchild, T., Clifton-Hadley, R., Mitchell, A., Story, A. et al., 2007, 'No increase in human cases of $M$. bovis disease despite resurgence of infections in cattle in the United Kingdom', Epidemiology and Infection 135, 4045. http://dx.doi.org/10.1017/S0950268806006509, PMid:16740186

Kazwala, R.R., Daborn, C.J., Kusiluka, L.J., Jiwa, S.F., Sharp, J.M. \& Kambarage, D.M., 1998, 'Isolation of Mycobacterium species from raw milk of pastoral cattle of the southern highlands of Tanzania', Tropical Animal Health and Production 30, 233 239. http://dx.doi.org/10.1023/A:1005075112393, PMid:9760715

Kazwala, R.R., Daborn, C.J., Sharp, J.M., Kambarage, D.M., Jiwa, S.F.H. \& Mbembati, N.A., 2001a, 'Isolation of Mycobacterium bovis from human cases of cervical adenitis in Tanzania: a cause for concern?', International Journal of Tuberculosis adenitis in Tanzania: a cause for concern?', Inte
and Lung Diseases 5, 87-91. PMid:11263522

Kazwala, R.R., Kambarage, D.M., Daborn, C.J., Nyange, J., Jiwa, S.F.H. \& Sharp, J.M., $2001 \mathrm{~b}$, 'Risk factors associated with the occurrence of bovine tuberculosis in cattle in the southern highlands of Tanzania', Veterinary Research Communications 25 609-614. http://dx.doi.org/10.1023/A:1012757011524, PMid:11767006

Keet, D.F., Kriek, N.P.J., Bengis, R.G. \& Michel, A.L., 2001, 'Tuberculosis in kudus (Tragelaphus strepsiceros) in the Kruger National 'Park', Onderstepoort Journal of Veterinary Research 68, 225-230. PMid:11769355

Keet, D.F., Kriek, N.P.J., Penrith, M-L., Michel, A. \& Huchzermeyer, H., 1996 'Tuberculosis in buffaloes (Syncerus caffer) in the Kruger National Park: Spread 'Tuberculosis in buffaloes (Syncerus caffer) in the Kruger National Park: Spread of the disease to other speci

Majoor, C.J., Magis-Escurra, C., Van Ingen, J., Boeree, M.J. \& Van Soolingen, D., 2011, 'Epidemiology of Mycobacterium bovis disease in humans, The Netherlands, 1993-2007', Emerging Infectious Diseases 17, 457-463. PMid:21392437

Mazet, J.A.K., Clifford, D.L., Coppolillo, P., Deolalikar, A.B., Erickson, J.D. \& Kazwala R.R., 2009, 'A "One Health" approach to address emerging zoonoses: The HAL project in Tanzania', PLoS Medicine 6, e1000190. http://dx.doi.org/10.1371/ journal.pmed.1000190, PMid:20016689

McNabb, S.J., Braden, C.R. \& Navin, T.R., 2002, 'DNA fingerprinting of Mycobacterium tuberculosis: Lessons learned and implications in the future', Emerging Infectious Diseases 8, 1314-1319. http://dx.doi.org/10.3201/eid0811.020402, PMid:12453363

Mfinanga, S.G., Morkve, O., Kazwala, R.R., Cleaveland, S., Sharp, M.J., Kunda, J. et al., 2004, 'Mycobacterial adenitis: Role of Mycobacterium bovis, non-tuberculous mycobacteria, HIV infection, and risk factors in Arusha, Tanzania', East African mycobacteria, HIV infection, and risk factors

Michel, A., De Klerk, L-M., Van Pittius, N., Warren, R. \& Van Helden, P., 2007, 'Bovine tuberculosis in African buffaloes: Observations regarding $M$. bovis shedding into water and exposure to environmental mycobacteria', BMC Veterinary Research 3 , 23. http://dx.doi.org/10.1186/1746-6148-3-23, PMid:17900356

Michel, A.L., 2002a, 'The epidemiology of M. bovis infection in South African wildlife' in Abstracts of the Veterinary European Network on Mycobacterium (VENOM) Symposium: DNA Fingerprinting of Bovine TB strains, October 24-26, 2002, Belfast, Northern Ireland.

Michel, A.L., 2002b, 'Implications of tuberculosis in African wildlife and livestock', Annals of New York Academy of Sciences 969, 251-255. http://dx.doi. org/10.1111/j.1749-6632.2002.tb04387.x, PMid:12381600

Michel, A.L., Bengis, R.G., Keet, D.F., Hofmeyr, M., De Klerk, L-M., Cross, P.C. et al., 2006, 'Wildlife tuberculosis in South African conservation areas: Implications and challenges', Veterinary Microbiology 112, 91-100. http://dx.doi.org/10.1016/j. vetmic.2005.11.035, PMid:16343819

Michel, A.L., Meyer, S., McCrindle, C.M. \& Veary, C.M., 2004, 'Community based veterinary public health systems, current situation, future trends and recommendations', FAO Expert Consultation on Community Based Veterinary Public Health Systems, viewed n.d., from http://www.fao.org/ag/againfo/ programmes/en/vph/events/expert_consult_report.pd
Michel, A.L., Müller, B. \& Van Helden, P.D., 2010, 'Mycobacterium bovis at the animalhuman interface: A problem, or not?', Veterinary Microbiology 140, 371-381. http://dx.doi.org/10.1016/j.vetmic.2009.08.029, PMid:19773134

Mignard, S., Pichat, C. \& Carret, G., 2006, 'Mycobacterium bovis infection, Lyon, France', Emerging Infectious Diseases 12(9), 1431-1433. http://dx.doi. France, Emerging Infectious Diseases 12
org/10.3201/eid1209.060209, PMid:17073096

Mikota, S.K., Peddie, L., Peddie, J., Isaza, R., Dunker, F., West, G. et al., 2001, 'Epidemiology and diagnosis of Mycobacterium tuberculosis in captive Asian elephants (Elephas maximus)', Journal of Zoology and Wildlife Medicine 32, 1-16. PMid:12790389

Muller, B., Hilty, M., Berg, S., Garcia-Pelayo, M.C., Dale, J., Boschiroli, M.L. et al., 2009 'African 1, an epidemiologically important clonal complex of Mycobacterium bovis dominant in Mali, Nigeria, Cameroon, and Chad', Journal of Bacteriology 191, 1951-1960. http://dx.doi.org/10.1128/JB.01590-08, PMid:19136597

Murphree, R., Warkentin, J.V., Dunn, J.R., Schaffner, W. \& Jones, T.F., 2011, 'Elephantto-human transmission of tuberculosis', Emerging Infectious Diseass 7, 366-371.

Murray, M. \& Alland, D.A., 2002, 'Methodological problems in the molecular epidemiology of tuberculosis', American Journal of Epidemiology 155, 565-571. http://dx.doi.org/10.1093/aje/155.6.565, PMid:11882530

Ngowi, B.J., Mfinanga, S.G., Bruun, J.N. \& Morkve, O., 2008, 'Pulmonary tuberculosis among people living with HIV/AIDS attending care and treatment in rural northern Tanzania', BMC Public Health 8, 341. http://dx.doi.org/10.1186/1471-2458-8-341, PMid:18826574

Osofsky, S.A., Cleaveland, S., Karesh, W.B., Kock, M.D., Nyhua, P.J., Starr, L. et al. (Eds.), 2005, Conservation and Development Intervention at the Wildlife/Livestock Interface: Implications for Wildlife, Livestock and Human Health, IUCN, Gland, Switzerland and Cambridge, UK.

Palmer, M.V., 2007, 'Tuberculosis: A reemerging disease at the interface of domestic animals and wildlife', Current Topics in Microbiology and Immunology 315, 195215. http://dx.doi.org/10.1007/978-3-540-70962-6_9

Rodriguez, J.G., Fissanoti, J.C., Del Portillo, P., Patarroyo, M.E., Romano, M.I. \& Cataldi, A., 1999, 'Amplification of a 500-base-pair fragment from cultured isolates of Mycobacterium bovis', Journal of Clinical Microbiology 37, 2330-2332. PMid:10364607

Rodriguez, J.G., Mejia, G.A., Del Portillo, P., Patarroyo, M.E. \& Murillo, L.A., 1995, 'Species-specific identification of Mycobacterium bovis by PCR', Microbiology 141 2131-2138. http://dx.doi.org/10.1099/13500872-141-9-2131, PMid:7496524

Romano, M.I., Alito, A., Bigi, F., Fisanotti, J.C. \& Cataldi, A., 1995, 'Genetic characterization of mycobacteria from South American wild seals', Veterinary Microbiology 47, 89-98. http://dx.doi.org/10.1016/0378-1135(95)00103-H

Romano, M.I., Alito, A., Fisanotti, J.C., Bigi, F., Kantor, I., Cicuta, M.E. et al., 1996 'Comparison of different genetic markers for molecular epidemiology of bovine tuberculosis', Veterinary Microbiology 50, 59-71. http://dx.doi.org/10.1016/03781135(95)00197-2

Sechi, L.A., Zanetti, S., Sanguinetti, M., Molicotti, P., Romano, L., Leori, G. et al., 2001, 'Molecular basis of rifampin and isoniazid resistance in Mycobacterium bovis strains isolated in Sardinia, Italy', Antimicrobial. Agents and Chemotherapy 45, 1645-1648. http://dx.doi.org/10.1128/AAC.45.6.16451648.2001, PMid:11353606

Shirima, G.M., Kazwala, R.R. \& Kambarage, D.M., 2003, 'Prevalence of bovine tuberculosis in cattle in different farming systems in the eastern zone of Tanzania', Preventive Veterinary Medicine 57, 167-172. http://dx.doi.org/10.1016/S01675877(02)00214-3

Smith, N.H., Berg, S., Dale, J., Allen, A., Rodriguez, S., Romero, B. et al., 2011, 'European 1: A globally important clonal complex of Mycobacterium bovis', Infection, Genetics and Evolution 11, 1340-1351. http://dx.doi.org/10.1016/j. meegid.2011.04.027, PMid:21571099

Torgerson, P. \& Torgerson, D., 2009, 'Benefits of stemming bovine TB need to be demonstrated', Nature 457, 657-657. http://dx.doi.org/10.1038/457657d, PMid:19194427

WHO/DFID, 2006, 'The control of neglected zoonotic diseases - a route to poverty alleviation. Report of a joint WHO/DFID-Animal Health Programme meeting with the participation of FAO and OIE', Geneva 20 and 21 Sept 2005, WHO, Geneva, viewed n.d., from http://www.who.int/zoonoses/Report_Sept06.pdf

WHO, 2004, 'Report of the WHO/FAO/OIE joint consultation on emerging zoonotic diseases -in collaboration with the Health Council of the Netherlands', 03-05 May 2004, Geneva, Switzerland.

Wirth, T., Hildebrand, F., Allix-Béguec, C., Wölbeling, F., Kubica, T., Kremer, K. et al., 2008, 'Origin, spread and demography of the M. tuberculosis complex', PLoS Pathogens 4, e1000160. http://dx.doi.org/10.1371/journal.ppat.1000160, PMid:18802459

Wolfe, N.D., Dunavan, C.P. \& Diamond, J., 2007, 'Origins of major human infectious diseases', Nature 447, 279-283. http://dx.doi.org/10.1038/nature05775, PMid:17507975

Woodroffe, R., Donnelly, C.A., Cox, D.R., Gilks, P., Jenkins, H.E., Johnston, W.T. et al., 2009, 'Bovine tuberculosis in cattle and badgers in localized culling areas', Journa of Wildlife Diseases 45, 128-143. PMid:19204342

Zumarraga, M.J., Martin, C., Samper, S., Alito, A., Latini, O., Bigi, F. et al., 1999 Usefulness of spoligotyping in molecular epidemiology of Mycobacterium bovisrelated infections in South America', Journal of Clinical Microbiology 37, 296-303. PMid:9889207 